AGENDA : Analisis Gender dan Anak,Vol. 3 (2), 2021, (Desember)

ISSN Print: $2615-1502$

ISSN Online: $2723-3278$

Tersedia online di

http://ecampus.iainbatusangkar.ac.id/ojs/index.php/agenda

\title{
STUDENTS' NEED ON TASK BASED LANGUAGE TEACHING WORKSHEET AT SMPN 2 TIGO LURAH BASED ON GENDER
}

\section{Suci Azani Putri}

SMPN 2 Tigo Lurah Kabupaten Solok, Sumatera Barat, Indonesia

suciazaniputri@gmail.com

\begin{abstract}
This study aims to investigate students' needs on task- based language worksheet at SMPN 2 Tigo Lurah based on gender differences. The research design was research and development research. The seven grade students of SMPN 2 Tigo Lurah was the sample. In collecting the data, the researcher used questionnaires and document. Then, it was analyzed descriptively. It was found that students really need task-based language teaching worksheet in term of pre-tasks task, the input of tasks and all materials stated in the curriculum. However, the differences are on the responses of the male and the female students. The female students gave high responses on the needs of task-based language teaching than male students. Hence, the task-based language teaching worksheet can be developed and used in the classroom.
\end{abstract}

Keywords: need analysis, worksheet, task based language teaching, gender 


\section{INTRODUCTION}

Nowdays, supplementary materials become the most crucial part in teaching and learning process. It helps students understand the lesson more by doing variety of tasks. It also help teacher to provide interesting classroom activity through asking students completing the tasks that cannot find in the text book. Worksheet is commonly used as supplementary teaching materials in teaching and learning English. It is one of teaching materials that assists students to have deep understanding about the lesson. Fannie and Rohati state that worksheet is one of teaching materials that commonly used in school to make further understanding about the lesson.

\section{DEPDIKNAS (2008:25) defines} worksheet as sheet of paper that provides guidelines for students to do programmed activities. Through completing the tasks, the students are asked to develop their skills and abilities. According to Praswoto (2011:204), students' worksheets are resources that consist of teaching materials that are constructed in such way so that students are expected to learn teaching material independently. Worksheet presents materials, summary and tasks related to materials. It is abbreviation of students' core materials that adjusted with the students. Furthermore, Asnaini (2016:62) states that worksheet is teaching material which can be designed related to students' needs and school characteristics. The appropriate worksheet is able to improve students' comprehensions and skills. Students' outcome is expected to increase through worksheet.

There are several previous researches about developing students' worksheet by using different approach. Some of them are Saputro, Setiawan \& Saragih (2018) who have studied the development of students worksheet (SW) based on inquiry to improve activity and learning outcomes in civic lesson of students grade VII. Then, Isrojikah (2016) who conducted study about developing Problem-Based Learning (PBL) worksheet for the eight grade students at junior high school. Then, Ikhsan and Handayani (2016) also conducted a study about the development of students' worksheet using scientific approach in curriculum materials.

Generally, students use commercial worksheet in the classroom. It is supplementary materials that provides by teacher to assist the students in teaching and learning process. However, not all the commercial worksheets meet the students' needs. Moreover, to make students do the tasks and have a deep understanding about the lesson, the need of appropriate approach is needed. Task based language teaching or TBLT is one of approach that used tasks as the center of teaching and learning process. It presents multiples tasks in order to helps student understand the lesson and created interesting classroom process. The development of worksheet by using task based language teaching approach can be an answer to students to meet the aims of the lesson.

In addition, Task Based Language Teaching (TBLT) is an approach 
developed from Communicative Language Teaching (CLT). Harmer (2007) states that TBLT was a natural extension of CLT since it emphasized on the task rather than the language itself. It focuses on student and presents students opportunities to actively engage in teaching and learning process through the task. As stated by Ellis (2003: ix), TBLT is seen as both refinement of CLT and a reaction of teacher centered learning. TBLT is not new in the foreign language teaching field since it is an approach that views language as communicative tools. It provides multiple opportunities for students to be able to use the language both speaking and writing trough learning activities designed to engage them in natural, practical and functional use of language for meaningful purpose. Teachers are able to use task based language teaching approach since it presents language learning and training skills in the process of performing tasks.

Furthermore, TBLT has improved students' self-confidence, learning attitudes, and thinking skills. When implementing TBLT in teaching learning, the students are able to use their knowledge and skills by interacting communicatively while doing tasks. A variety of task that provides by TBLT can be depended on students' needs, interests, and language proficiency levels. It assists the students what they need in their real life or to accomplish the goals of teaching learning (Lee in Chuang, 2010).

Moreover, as one of language teaching approach, there are many studies conducted on TBLT. Some studies focuses on implementing TBLT. Fan-Jian (2005) studied the effectiveness of implementing TBLT in a Taiwanese primary school. She found that TBLT could enhance students' motivation and attitudes toward learning English. Then, Hutagalung and Purwati
(2014) who conducted studied about the implementation of Task-Based Language Teaching to teach speaking descriptive to the first graders of junior high school students. They found that the implementation was effective to engage and motivate the students to speak descriptive actively trough the compilation of a communicative task. And most of the students got satisfying scores in speaking descriptive.

In addition, there are some studies about improving English skills toward TBLT. Mudra (2016) conducted a study in enhancing students' speaking skill through TBLT at English Department of STAIN Kerinci. A study was also conducted by Munirah and Muhsin (2015) on using Task-Based approach in Improving the students' speaking accuracy and fluency. The result of study shows that Task Based Language Teaching approach is an appropriate method to improve learners' speaking skill. It also gives significant contributions in learning process of speaking and accuracy. Hasan (2014) also conducted study about the effect of using task-based learning in teaching English on the oral performance of the secondary school students. He found that it is effectives to use task based learning in teaching English as the foreign language. Gunawan (2016) conducted study on the effect of TBLT approach in developing speaking skill of the eight grade students of SMPN 6 Watampone and their attitude toward English. He found that TBLT improves students' speaking skill and the students' attitude toward TBLT is positive.

In addition, this study investigated based on genders for seven grade students at junior high school where gender is differences are differences in characteristics, traits and ways of thinking between men and women (Desiningrum, 
Indriana, and Siswati: 2017). According to Astalini,, Darmaji, , Kurniawan, \& Wulandari, (2021:209) gender is categorized as men and women, where women's ways of thinking are more apparent, and their emotions are more organized than men who are more realistics or use their minds more. This gender difference can be aspect in the differences in students' needs. Due the problem, this study is carried out to analyze students' need on task based language teaching worksheet for seven grade students at junior high school based on gender.

\section{METHOD}

This study was research and development on task based language teaching worksheet was based on 15 students of SMPN 2 Tigo Lurah students involved. To achieve the purpose, several methods of data collected were involved, namely; questionnaires and documents analysis. The purpose of distributing questionnaire to students was to find out students' opinion and need related to task based language teaching worksheet. Then, document analysis from teachers' documents such as syllabus and textbook was used in order to know the basic competences, lesson and materials should be put in worksheet. There were two types of data; quantitative data and qualitative data. Quantitative data were gained through questionnaire. The questionnaire was administered to seven grade students of SMPN 2 Tigo Lurah to see the need for task based language teaching worksheet. In addition, qualitative data were gathered from document analysis form. The result of the content analysis will be discussed descriptively.

\section{FINDINGS AND DISCUSSIONS}

Need analysis is the core process in research and development study. Need analysis aimed to collect the data about the students based on gender. The data were obtained by using questionnaires. The questionnaires were given to the seven grade students of SMPN 2 Tigo Lurah. The results of students' need were derived from document analysis and questionnaire. The document analysis consisted of data to investigate syllabus and text book used for seven grade students of SMPN 2 Tigo Lurah.

\section{a. Learning Needs}

For identifying the students' needs, the questionnaires were distributed to the students and their scores were analyzed based on the score of each questionnaire item. There were seven indicators adapted from Hutchinson and Waters (1987) about learning needs and Willis (1996) about framework of Task Based Language Teaching. The indicators 1-4 were related to the needs of the students. They are students' attitude toward worksheet, the input of pre task, the way student do the task, the input of task cycle, the task that students need, the time worksheet takes place and topic of task that students need.

The questionnaire for the students contained four responses written based on the four points of Likert scale namely Strongly Agree (SS), Agree (S), Disagree (TS), and Strongly Disagree (STS).

\section{1) Students' attitude toward worksheet \\ There were some sub-indicators included to collect information related to students' attitude toward worksheet. There were four items that developed from the indicators. The results of analysis were:}


AGENDA : Analisis Gender dan Anak,Vol. 3 (2), 2021, (Desember)

ISSN Print: $\underline{2615-1502}$

ISSN Online: $\underline{2723-3278}$

Tersedia online di

http://ecampus.iainbatusangkar.ac.id/ojs/index.php/agenda

Table 1. Students' Attitude toward Worksheet

\begin{tabular}{|c|l|c|c|}
\hline No & Statements & Male & Female \\
\hline 1 & $\begin{array}{l}\text { I need } \\
\text { worksheet to } \\
\text { learn English } \\
\text { subject }\end{array}$ & 3.00 & 3.20 \\
\hline 2 & $\begin{array}{l}\text { I like studying } \\
\text { by worksheets } \\
\text { because it has } \\
\text { variety of tasks }\end{array}$ & 3.70 & 3.60 \\
\hline 3 & $\begin{array}{l}\text { I like studying } \\
\text { by worksheets } \\
\text { because it looks } \\
\text { attractive }\end{array}$ & 3.50 & 3.60 \\
\hline 4 & $\begin{array}{l}\text { Learning } \\
\text { English with } \\
\text { LKS is easier to } \\
\text { understand }\end{array}$ & 3.60 & 4.00 \\
\hline Average & 3.45 & 3.60 \\
\hline
\end{tabular}

The table shows that the students' male attitudes toward worksheet are very high which can be seen from the average score of 3.45. Then, students' female attitudes toward worksheet are very high which can be seen from the average score of 3.60. The item 1 until 4 indicates that the students need worksheet to learn English because worksheet has variety of task, attractive and easy to understand. Based on the analysis of students' attitude toward worksheet, it is clear that the female students need worksheet than male students to learn English.

\section{2) The task that students need in Pre-Task}

There were some sub-indicators included to collect information related to task that students' need in pre-task. There were four items that developed from the indicators. The results of analysis were:

Table 2. The Input of Pre-Task

\begin{tabular}{|c|c|c|c|}
\hline No & Statements & Male & Female \\
\hline 1 & $\begin{array}{l}\text { I want role } \\
\text { play activity as } \\
\text { pre-task }\end{array}$ & 2.6 & 3.2 \\
\hline 2 & $\begin{array}{l}\text { I want match } \\
\text { words and } \\
\text { pictures as pre- } \\
\text { task }\end{array}$ & 3.8 & 3.6 \\
\hline 3 & $\begin{array}{l}\text { I want classify } \\
\text { word as pre- } \\
\text { task }\end{array}$ & 2.6 & 3 \\
\hline 4 & $\begin{array}{l}\text { I want } \\
\text { complete the } \\
\text { picture as pre- } \\
\text { task }\end{array}$ & 3.5 & 3.6 \\
\hline \multicolumn{2}{|c|}{ Average } & 3.12 & 3.35 \\
\hline
\end{tabular}

Based on the description of questionnaire data, the students need all the input of pre-task. However, the needs of female students are higher than male students. Based on the analysis, it is clear that the students need all the input of pretask and the highest response is female students.

\section{3) The input of task}

There were some sub-indicators included to collect information related to the input of task that students need. There were four items that developed from the indicators. The results of analysis were: 
AGENDA : Analisis Gender dan Anak,Vol. 3 (2), 2021, (Desember)

Table 3. The Input of Task Cycle

\begin{tabular}{|c|l|c|c|}
\hline No & Statements & Male & Female \\
\hline 1 & $\begin{array}{l}\text { I want tasks } \\
\text { given through } \\
\text { audio }\end{array}$ & 3.10 & 3.4 \\
\hline 2 & $\begin{array}{l}\text { I want tasks } \\
\text { given through } \\
\text { picture }\end{array}$ & 3.00 & 3.6 \\
\hline 3 & $\begin{array}{l}\text { I want tasks } \\
\text { given through } \\
\text { text }\end{array}$ & 3.20 & 3.6 \\
\hline 4 & $\begin{array}{l}\text { I want tasks } \\
\text { given through } \\
\text { game }\end{array}$ & 3.30 & 3.4 \\
\hline Average & 3.15 & 3.35 \\
\hline
\end{tabular}

There were four items developed about the input of task that students need. All items were related to the respondents' opinions about the input of task that students need. The male students' responses are 3.15 to the input of task. Besides, the female responses are 3.35 to the input of task. It can be concluded that, the female students needs all the input of tasks than male students even they need all the input of tasks.

\section{4) The topic of task that students need}

There were some sub-indicators included to collect the information related to the topics that students need. There were four items that developed from the indicators. The results of analysis were:

Table 4. The Topic of Task that Students Need

\begin{tabular}{|c|c|c|c|}
\hline No & Statements & Male & Female \\
\hline 1 & $\begin{array}{l}\text { I want task on } \\
\text { the topic of } \\
\text { asking } \\
\text { questions and } \\
\text { information } \\
\text { about the } \\
\text { characteristics } \\
\text { of things, } \\
\text { animals and } \\
\text { people around } \\
\text { us }\end{array}$ & 3.50 & 3.80 \\
\hline 2 & $\begin{array}{l}\text { I want task on } \\
\text { the topic of } \\
\text { asking } \\
\text { questions and } \\
\text { information } \\
\text { about the } \\
\text { actions and } \\
\text { functions of } \\
\text { things, animals } \\
\text { and people } \\
\text { around us }\end{array}$ & 3.30 & 3.40 \\
\hline 3 & $\begin{array}{l}\text { I want task on } \\
\text { the topic of } \\
\text { describing } \\
\text { things, animals } \\
\text { and people } \\
\text { around us }\end{array}$ & 3.00 & 3.80 \\
\hline 4 & $\begin{array}{l}\text { I want task on } \\
\text { the topic of } \\
\text { understanding } \\
\text { the lyrics of } \\
\text { song }\end{array}$ & 3.70 & 3.40 \\
\hline
\end{tabular}




\begin{tabular}{|l|l|l|}
\hline Average & 3.37 & 3.60 \\
\hline
\end{tabular}

There were four items developed about the topics of task that students need. The table shows that all materials which are stated in syllabus of the 2013 curriculum were highly needed by the students to be learnt. Based on the analysis of students need about the topics of task that needed by the students, it is clear that the male and female students need all the topics stated in 2013 curriculum.

\section{b. Document Analysis}

In document analysis, researcher was collected the specific information from teachers' documents such as syllabus from SMPN 2 Tigo Lurah. The aim is to know the basic competences, lesson and materials that should be put in the product. The content was analyzed and generated by the researcher to support the developed product. They are consisted of basic competences, lessons, and materials.

The results showed that there are eight basic competences that should be mastered by the seven grade students in teaching and learning English. They are focused on a number of lesson such as it's a beautiful day, we love what we do, I'm proud of Indonesia and That's what friend supposed to do. Thus, the mapping of basic competences based on syllabus and 2013 curriculum is one of the guidance for the researcher to develop the product particularly in designing the content of the product.

Need analysis was done as a starting point before designing a product. It was done to see the students' need based the 2013 curriculum. Need analysis is the process of getting information for developing a curriculum where objectives and goals should be understood before coming to the process of design. The information was collected from teachers' documents and students in form of fundamental questions to guide designer making a relevant content, useful, and meet the needs.

The result shows that the students (male and female) needed all materials that presented in 2013 curriculum which are four units such as what does she look like, we love what we do, I'm proud of my parents and love who you are. Since the focus of developed product is task based language teaching worksheet, therefore the researcher asked students' need about tasks in worksheet. This result is supported by the research from Oliver, Rhonda, Grote., E., Rochecouste., J., Exell, Michael (2013) entitled A taskbased needs analysis for Australian Aboriginal students: Going beyond the target situation to address cultural issues. They found benefits of a needs analysis for triangulating multiple data sources and methods to identify the actual target tasks, including social workplace interactions as well as cultural issues.

\section{CONCLUSION}

In summarizing, students need task based language teaching worksheet in teaching and learning in the classroom. The inputs of pre task that students' needs are all the input of tasks, namely role play, matching words and pictures, classify word and complete the picture task. The inputs of task that students need are picture, text, audio and game. The topics that students needs are characteristics of things, animals and people, functions of things, animals and people, describing things, animals and people and song. The differences are on 
the level of the responses of the needs. The female students gave high responses on the need of developing task based language teaching than male students. Hence, the female students need task based language teaching worksheet than male students.

In addition, for further researcher, the writer suggested to use to produce a product. Since this research focuses only on the developing task based language teaching for seven grade students of SMPN 2 Tigo Lurah, it is extensively suggested to the other researchers to do the next research on another grade. Another possibility, for other researcher may conduct the developing worksheet by using other approaches.

\section{REFERENCES}

Asnaini, A. 2016. Pengembangan LKPD Berbasis Pendekatan Scientific Untuk Meningkatkan Hasil Belajar dan Aktivitas Peserta Didik Pada Materi Larutan Penyangga.

Astalini, A., Darmaji, D., Kurniawan, D. A., \& Wulandari, M. (2021). Male or Female, who is better? Students' Perceptions of Mathematics Physics E-Module Based on Gender. Indonesian Journal on Learning and Advanced Education (IJOLAE), 3(3), 207-224.

Chuang, Y.Y. 2010. Task-Based Language Approach to Teach EFL Speaking. Department of Applied Foreign Language Taiwan

DEPDIKNAS (2008). Panduan Pengembangan Bahan Ajar.

Desiningrum, D. R., Indriana, Y., \& Siswati, S. (2017). Intensi penggunaan gadget dan kecerdasan emosional pada remaja awal. Prosiding Temu Ilmiah
Nasional X Ikatan Psikologi Perkembangan Indonesia, 1 .

Fan-Jian IC. 2005. The effectiveness of Implementing Task-Based Instruction in a Primary School in Taiwan. Unpublished Master Thesis, Yuan Ze University, Taiwan, R.O.C

Gunawan, G. 2016. The Effect of TaskBased Language Teaching (TBLT) Approach in Developing Speaking Skill of the Eighth Grade Students of SMP Negeri 6 Watampone and Their Attitude Toward English. Perspektif: Jurnal Pengembangan Sumber Daya Insani, 1(2), 103-109 Harmer, J.(2007). How to Teach English $\left(2^{\text {nd }} e d\right)$. England :Pearson Education Limited.

Hasan, Ali Alsagheer A. 2014. The Effect of Using Task-Based Learning in Teaching English on the Oral Performance of the Secondary School Students. International interdisciplinary journal of education, 1(1045), 1-15.

Hutagalung, Evi Y. and Purwati, O. 2014. The implementation of taskbased language teaching to teach Speaking descriptive to the first graders of junior high school.EJurnal Unesa. Volume 01 Nomor 01 Tahun 2014

Hutchinson, T., and Waters, A. 1978. English for Specific Purposes: A learning-Centered Approach. Cambridge: Cambridge University Press.

Ikhsan, M. Khairi; SB, Handayani. (2016). The Developmentof Students'worksheet Using Scientific Approach on Curriculum Materials. Proceedings of ISELT FBS Universitas Negeri Padang, 2016, 4.2: 74-87. 
Isrokijah, I. (2016). Developing ProblemBased Learning (PBL) Worksheets for the Eight Grade Students at Junior High School. LLT journal: A Journal on language and language teaching, 18(2), 99-106.

Mudra, H. 2016. Enhancing Students Speaking Skill through Task-Based Language Teaching (TBLT) at English Tadris Department of STAIN Kerinci. Al-Ta Lim Journal, 23(1), 78-87.

Munirah \& Muhsin, M. A. 2015. Using Task-Based Approach in Improving the Students' Speaking Accuracy and Fluency. Journal of Education and Human Development, 4(3), 181-190.

Oliver, R., Grote, E., Rochecouste, J., \& Exell, M. (2013). A Task-Based Needs Analysis for Australian Aboriginal Students: Going Beyond the Target Situation To Address Cultural Issues. International Journal of Training Research, 11(3), 246-259.

Praswoto, A. 2013.Panduan Kreatif Membuat Bahan Ajar Inovatif.Yogyakarta:Diva Press

Saputro, R., Setiawan, D., \& Saragih, D. (2019, May). The Development of Students Worksheet (SW) based on Inquiry to Improve Activity and Learning Outcomes in Civic Lesson of Students Grade VII. In 1st International Conference on Social Sciences and Interdisciplinary Studies (ICSSIS 2018). Atlantis Press.

Willis, D.1996. A Framework for TaskBased Learning. Londond: Longman 